\title{
An Unpleasant Duty
}

By H. M. RAYNER, Ituna, Sask.

Walking home to lunch on a sunny day in June of this year, I came upon a hurt robin. It fluttered away from me, its breast dragging along the ground, and I knew that its legs must be broken.

Using my cap as a net, I easily caught it. The poor thing cried out pitifully as I put my hand around it, holding its wings, which were not hurt, in the folded position. I found one leg broken close to the body and badly mangled. The other was broken at the ankle. There was only one thing to be done-kill the robin as quickly and mercifuliy as possible.

It had stopped crying out and rested passively in my hand as I carried it home. I sought out my small benchaxe, which I always keep sharp. I had decided that instantaneous decapitation was the best I could do. As I prepared for this very unwelcome task, I thought of the young mountaineer in Earle Birney's fine poem "David," and of a certain English noble of historical fame who, on trying the edge of the executioner's axe, said drily: "Ay, this is sharp medicine, but it cures all diseases."

In order to expose the bird's neck and save my own fingers, I had to change my hold and take her by the wings. Her first response to this was to twist her head around and deliver a series of savage pecks. These suddenly ceased. The birds head drooped, its beak gaped, its eyes closed, its muscles went limp. I was to be spared the job of putting her out of pain. She was dying in my hand.

Or was she? Mindful that the game of playing 'possum is one played at by more than 'possums, I had best wait and see. Soon I felt a slight movement, a slow tensioning of the body. Her eyes slowly opened, bright, full, and alive as ever. When the show of fight had failed, she had tried one more trick in an attempt to escape. An ill advised attempt, had she but known it.

By what freak accident her legs got broken is a complete mystery to me. Perhaps some reader may have an answer.

\section{Sanctuary}

By ERIC A. DOWSON, Nanaimo, B.C.

There is a cabin that I know Built on a rise, and down below A Prairie stream goes singing by, Where poplars etch a Prairie sky.

No formal garden stands to grace That small and unpretentious place, Furnished in such a modest way, All so unlike this modern day.

But God's green country spreads around.

There's songs of birds and rustling sound

Of wind that ripples through the grain,

And that fresh Earth-smell after rain.

Unfrequented save by the few, Beauty dwells there, and quiet too.

One can find sanctuary there

From progress and life's hectic stir. 